\section{Ranking Cultivated Blueberry for Mummy Berry Blight and Fruit Infection Incidence Using Resampling and Principal Components Analysis}

\author{
Mark K. Ehlenfeldt ${ }^{1,3}$, James J. Polashock, and Allan W. Stretch ${ }^{2}$ \\ USDA-ARS, Genetic Improvement of Fruits and Vegetables Laboratory, \\ Henry A. Wallace Agricultural Research Center, Beltsville, MD 20705
}

\section{Matthew Kramer \\ USDA-ARS, Biometrical Consulting Service, Henry A. Wallace Agricultural Research Center, Beltsville, MD 20705}

Additional index words. Vaccinium spp., Monilinia vaccinii-corymbosi, disease resistance, screening, common garden

\begin{abstract}
Mummy berry disease of blueberry has two distinct phases: a blighting phase that infects emerging shoots and leaves early in the spring and a flower infection phase that ultimately leads to infected (mummified) fruit. Cultivated blueberry (Vaccinium spp.) genotypes that are resistant to one phase are not necessarily resistant to the other phase. The resistance of cultivated blueberry (Vaccinium spp.) genotypes to each phase of the disease is different. A large number of cultivars were screened for resistance to each phase. Cultivar standards (cultivars with well-documented responses to the disease) were used in the screening to evaluate long-term variation and aid comparisons across years. Using nine standards for the blight phase, 125 cultivars were tested and ranked for relative resistance using a ranking system based on resampling and principal component analysis. Similarly, using six standards for the flower/fruit infection stage, 110 blueberry cultivars were tested and ranked for relative resistance. Cultivar rankings show that lowbush cultivars and other types possessing high percentages of lowbush germplasm are generally more resistant to both phases of the disease. Among highbush cultivars, Bluejay is reliably resistant to both phases. Documentation of resistance to each phase will allow selection of cultivars for planting in affected areas and will facilitate the development of breeding strategies to produce cultivars with superior resistance.
\end{abstract}

Breeding and selection for plant disease resistance remains one of the most economically and environmentally sound approaches to improving crop quality and yield (Lynch et al., 2003). As part of a long-term breeding program in blueberries, we have screened and identified sources of resistance to important diseases such as anthracnose (Ehlenfeldt et al., 2006; Polashock et al., 2005), Botryosphaeria stem blight (Polashock and Kramer, 2006), and Phomopsis twig blight (Polashock and Kramer, 2006). Another important disease of blueberry is mummy berry caused by the ascomycete Monilinia vaccinii-corymbosi (Reade) Honey (Hildebrand et al., 1995). Mummy berry disease is unique in that it has two distinct phases. The first phase is incited by ascospores produced by fungal apothecia (mummy cups) in early spring that cause a blighting of young shoots and flowers.

Received for publication 6 Oct. 2009. Accepted for publication 19 June 2010.

${ }^{1}$ Current address: P.E. Marucci Center for Blueberry and Cranberry Research, 125A Lake Oswego Road, Chatsworth, NJ 08019.

${ }^{2}$ Retired.

${ }^{3}$ To whom reprint requests should be addressed; e-mail mark.ehlenfeldt@ars.usda.gov.
Conidia produced on the blighted tissue are wind- and bee-transferred to open flowers initiating the flower infection and fruit rot stage (Batra, 1983; Batra and Batra, 1985). Although chemical controls are currently adequate, inherent host resistance is desirable. Sources of resistance to both phases have been investigated in blueberry (Ehlenfeldt and Stretch, 2000; Ehlenfeldt et al., 1996, 1997; Lehman et al., 2007; Pepin and Toms, 1969; Stretch and Ehlenfeldt, 2000; Stretch et al., 1995, 2001)

A previous study examined the variability inherently present in the screening of resistance to mummy berry blight and fruit rot (Ehlenfeldt et al., 2009, 2010). The study concluded that at least 8 years of testing is required to establish accurate numerical estimates of resistance in a nursery setting. Eight or more years of testing are not practical on large numbers of cultivars. As part of a concurrent screening process, more than 100 cultivars were evaluated for 3 to 4 years for resistance to one or both phases of mummy berry. To reconcile this difficulty in generating reliable resistance values, the information from shorter-term testing was mathematically transformed and ranked against the previously tested standards with the goal of identifying cultivars suitable for planting in areas where disease pressure is high and also for identification of useful breeding material. Although the resistance rankings for some of the cultivars with fewer years of data may be imprecise, these data are useful for understanding the short-term infection levels, their range, and their variability.

\section{Materials and Methods}

Plant material. All plant materials used in the screenings were named cultivars that are available either through nurseries or the USDA-ARS National Clonal Germplasm Repository. All plants were 5 to 6 years old and were maintained in $2.84-\mathrm{L}$ pots in a $1: 1$ mixture (by volume) of sand and peat. Plants were maintained in coldframes, pruned to the crown each winter, and allowed to regrow several times. Detailed background and pedigree information on the cultivars used in this study may be obtained by request from the authors. Additional information on some cultivars is available in the Germplasm Resources Information Network (http://www. ars-grin.gov/npgs) online database.

Blight screening materials. Nine cultivars were selected as standards for blight screening based on earlier testing (Ehlenfeldt and Stretch, 2000; Stretch et al., 1995). The standards were chosen to represent a broad range of resistance (from low to high) as well as to represent both highbush (HB, Vaccinium corymbosum L.) and rabbiteye (RE, Vaccinium ashei Reade) species. The cultivars Bluejay (HB), Brightwell (RE), Callaway (RE), Coastal (RE), Coville (HB), Northblue (a half-high type, i.e., a lowbush $\times$ highbush hybrid), Sunrise (HB), and Toro (HB) were included from 1996 to 2007. 'Climax' (RE) was included from 1996 to 2006. All cultivars were typically screened for 3 years along with the cultivar standards. Additional years of screening were added if the results from previous years appeared to be particularly variable. Approximately 35 cultivars were screened in each year. A total of 125 cultivars were screened for 2 to 6 years (Table 1). More than $75 \%$ were screened for either 3 or 4 years. Those screened for only 2 years were limited by plant availability.

Fruit infection screening materials. Six cultivars were selected as standards for fruit rot screening based on earlier testing data (Stretch and Ehlenfeldt, 2000) and the fact that they represented a range of resistance responses from low to high. The six "standard" cultivars used in all screenings from 1995 to 2007 were: Atlantic (HB), Bluejay (HB), Blueray (HB), Northsky (half-high), Rancocas (HB), and Sierra (HB). A total of 110 cultivars were coscreened with the standards for 2 to 5 years (Table 2). More than $90 \%$ of the cultivars were screened for 3 to 4 years.

Blight screening methods. The tests were conducted outdoors in a randomized complete block design with five blocks and one potted plant of each cultivar per block. Potted plants were arranged in a grid pattern in each block with the specific dimensions of the grid determined by the number of entries (cultivars) 
and the space allocated each year. The space between plants averaged $0.45 \mathrm{~m}$ and blocks were laid out linearly. Plants for blight evaluation were typically 30 to $60 \mathrm{~cm}$ in height and were maintained as noted previously. Pseudosclerotia (mummies) were collected in September and October of each year from the field at the P.E. Marucci Center for Blueberry and Cranberry Research, Chatsworth, NJ. Mummified fruit were planted $(\approx 5$ per pot) into soil-filled 0.9 -L plastic pots and overwintered in plastic-covered coldframes. Pots were watered as needed to maintain moisture. Emergence of apothecia typically started in early April. Pots with newly emerged apothecia were removed from the coldframes and evenly spaced within and around the periphery of the experiment area to provide a uniformly distributed source of inoculum. To enhance the infection process, the entire plot received supplemental misting for $1 \mathrm{~h}$ every evening during ascospore release (applied volume $\approx 5 \mathrm{~mm} /$ day).

Trials were typically set up starting the first week of April with the timing of plant exposure to inoculum determined by initiation of shoot development in the cultivars. Once exposed to inoculum, plants were examined for blighted shoots on a weekly basis between early May, when symptoms first became visible, and late May/early June, when no further new blighting appeared. Blighted shoots were tabulated and removed at each inspection to avoid overestimating blight incidence. At the end of the blight period, remaining healthy shoots were counted on each plant so that the percentage of blighted shoots could be calculated. The mean number of shoots evaluated per cultivar per year was 77 with a SD of 41 .

Fruit infection screening methods. Plants for fruit infection evaluation were typically 50 to $80 \mathrm{~cm}$ tall and maintained as noted previously. Flower/fruit infection screening was conducted in a shadecloth-covered (55\% transmission) coldframe. Plants were arranged in a randomized complete block design of five blocks with one pot of each cultivar per block. The space between plants averaged $0.45 \mathrm{~m}$ between rows and $0.36 \mathrm{~m}$ between plants within rows. In all years, heavily blighted plants of 'Bluehaven' and 'Blueray' (in 2.8-L plastic pots) with sporulating infections were evenly distributed between every two rows of plants to serve as inoculum sources located within $0.5 \mathrm{~m}$ or less of the plants to be tested. In previous studies, 'Bluehaven' and 'Blueray' had averaged $64 \%$ and $36 \%$ blight, respectively (considered highly susceptible) (Ehlenfeldt et al., 1996). Additional plants of 'Bluehaven' and 'Blueray' were added over time, as necessary, to maintain inoculum levels. To facilitate transfer of conidia from the blighted tissue to the stigmata, two hives of honeybees were placed in the netted coldframe, one at each end of the experiment area. Open flowers were removed from the test plants before setting the inoculum plants and bees in the coldframe. The experiment area was sprinkler-irrigated ( $22 \mathrm{~mm} /$ day) every evening
Table 1. Mummy blight estimates, ranks, and raw percentages compared with blueberry cultivar standards (bold) listed in order of increasing susceptibility.

\begin{tabular}{|c|c|c|c|c|c|c|c|}
\hline Accession & Estimate $^{\mathrm{z}}$ & $\begin{array}{l}\text { SE of the } \\
\text { estimate }\end{array}$ & Rank & $\begin{array}{l}\text { SD of } \\
\text { rank }\end{array}$ & $\begin{array}{c}\text { Raw } \\
\text { avg. }(\%)^{y}\end{array}$ & $\begin{array}{c}\text { Raw } \\
\text { range }(\%)\end{array}$ & $\begin{array}{l}\text { No. of } \\
\text { years }^{\mathrm{x}}\end{array}$ \\
\hline$\overline{\text { Brunswick (LB) }}{ }^{\mathrm{w}}$ & 3.43 & 0.04 & 1 & 0.50 & 19.3 & $18.1-20.6$ & 2 \\
\hline Concord (HB) & 3.42 & 0.06 & 2 & 0.50 & 12.4 & $5.2-25.3$ & 4 \\
\hline Grover (HB) & 3.07 & 0.06 & 3 & 0.41 & 13.6 & $4.7-22.4$ & 2 \\
\hline Blomidon (LB) & 3.01 & 0.05 & 4 & 0.41 & 11.6 & $0.0-28.0$ & 4 \\
\hline Aron $(\mathrm{EX})$ & 2.86 & 0.09 & 5 & 0.43 & 0.4 & $0.3-0.5$ & 3 \\
\hline Brigitta Blue (HB) & 2.66 & 0.07 & 6 & 0.52 & 25.5 & $21.2-27.8$ & 3 \\
\hline Augusta (LB) & 2.57 & 0.09 & 7 & 0.46 & 7.3 & $1.2-16.9$ & 3 \\
\hline Fundy (LB) & 2.40 & 0.04 & 8 & 0.82 & 9.7 & $2.4-17.4$ & 4 \\
\hline Bluejay (HB) & 2.38 & 0.04 & 9 & 0.66 & 19.7 & $0.0-55.9$ & 11 \\
\hline Toro (HB) & 2.32 & 0.04 & 10 & 0.73 & 22.3 & $0.0-58.5$ & 10 \\
\hline Chippewa (HH) & 2.28 & 0.07 & 11 & 1.31 & 28.6 & $19.4-45.0$ & 3 \\
\hline Olympia (HB) & 2.24 & 0.05 & 12 & 0.63 & 32.4 & $7.0-61.8$ & 3 \\
\hline Greta (HB) & 1.71 & 0.10 & 13 & 0.84 & 26.0 & $0.0-54.6$ & 3 \\
\hline Nui (HB) & 1.70 & 0.04 & 14 & 0.78 & 38.5 & $24.0-46.4$ & 3 \\
\hline Liberty (HB) & 1.65 & 0.11 & 15 & 1.37 & 10.4 & $1.6-19.2$ & 2 \\
\hline Reveille (HB) & 1.54 & 0.05 & 16 & 1.16 & 39.5 & $18.4-52.9$ & 3 \\
\hline Hagood (RE) & 1.48 & 0.07 & 17 & 1.35 & 37.3 & $8.0-66.6$ & 2 \\
\hline Ornablue (EX) & 1.42 & 0.05 & 18 & 1.66 & 45.9 & $35.7-59.6$ & 3 \\
\hline Aurora (HB) & 1.41 & 0.10 & 19 & 1.94 & 14.3 & $2.4-26.2$ & 2 \\
\hline Georgiagem (SHB) & 1.40 & 0.05 & 20 & 1.41 & 42.4 & $14.2-64.1$ & 3 \\
\hline Zuckertraube (LB) & 1.36 & 0.09 & 21 & 1.80 & 31.1 & $10.1-55.6$ & 3 \\
\hline Reka (HB) & 1.25 & 0.09 & 22 & 1.50 & 41.9 & $20.1-66.1$ & 3 \\
\hline Bounty (HB) & 1.24 & 0.09 & 23 & 1.58 & 45.2 & $16.1-66.2$ & 3 \\
\hline Cumberland (LB) & 1.10 & 0.03 & 24 & 1.33 & 30.2 & $5.0-58.1$ & 4 \\
\hline Centurion (RE) & 1.09 & 0.11 & 25 & 3.33 & 43.5 & $13.9-85.6$ & 3 \\
\hline Chignecto (LB) & 1.05 & 0.04 & 26 & 1.80 & 19.2 & $5.2-39.3$ & 3 \\
\hline Echota (HB) & 1.04 & 0.03 & 27 & 1.56 & 25.9 & $1.3-65.9$ & 3 \\
\hline Delite (RE) & 1.03 & 0.07 & 28 & 2.83 & 52.1 & $33.4-77.3$ & 3 \\
\hline Coastal (RE) & 1.03 & 0.03 & 29 & 1.41 & 35.6 & $5.2-65.6$ & 9 \\
\hline Bluebelle (RE) & 1.02 & 0.05 & 30 & 2.24 & 31.8 & $3.2-85.1$ & 6 \\
\hline South Moon (SHB) & 0.93 & 0.03 & 31 & 1.50 & 44.6 & $22.1-58.8$ & 3 \\
\hline Callaway (RE) & 0.89 & 0.03 & 32 & 1.99 & 36.1 & $4.2-76.0$ & 8 \\
\hline Montgomery (RE) & 0.88 & 0.06 & 33 & 2.59 & 12.8 & $5.9-26.9$ & 3 \\
\hline Yadkin (RE) & 0.88 & 0.03 & 34 & 1.88 & 33.6 & $4.7-86.7$ & 3 \\
\hline Bladen (SHB) & 0.87 & 0.13 & 35 & 6.56 & 35.3 & $13.3-63.0$ & 3 \\
\hline Northcountry (HH) & 0.87 & 0.04 & 36 & 2.71 & 50.5 & $33.3-59.3$ & 3 \\
\hline Nelson (HB) & 0.83 & 0.03 & 37 & 2.13 & 47.9 & $29.6-66.7$ & 3 \\
\hline Chanticleer (HB) & 0.81 & 0.06 & 38 & 3.32 & 41.4 & $6.1-87.6$ & 4 \\
\hline Walker (RE) & 0.80 & 0.04 & 39 & 3.01 & 59.1 & $43.1-75.0$ & 2 \\
\hline Legacy (SHB) & 0.79 & 0.02 & 40 & 1.90 & 54.0 & $44.8-64.6$ & 3 \\
\hline Myers (RE) & 0.78 & 0.07 & 41 & 3.47 & 27.1 & $4.2-58.8$ & 4 \\
\hline Chandler (HB) & 0.78 & 0.04 & 42 & 2.28 & 43.9 & $4.3-88.2$ & 4 \\
\hline Windsor (SHB) & 0.76 & 0.06 & 43 & 2.93 & 47.4 & $42.4-57.3$ & 3 \\
\hline Gem (HB) & 0.74 & 0.09 & 44 & 4.45 & 17.0 & $7.8-26.1$ & 2 \\
\hline Cara's Choice (SHB) & 0.71 & 0.04 & 45 & 1.62 & 33.7 & $0.4-52.0$ & 3 \\
\hline Ascorba $(\mathrm{HB})^{\mathrm{v}}$ & 0.67 & 0.06 & 46 & 1.26 & 35.1 & $0.0-86.0$ & 4 \\
\hline Garden Blue (RE) & 0.51 & 0.04 & 47 & 0.96 & 67.1 & $61.1-73.2$ & 2 \\
\hline Premier (RE) & 0.50 & 0.06 & 48 & 1.61 & 59.9 & $44.9-88.2$ & 3 \\
\hline Sunrise (HB) & 0.47 & 0.04 & 49 & 1.57 & 44.6 & $2.3-84.0$ & 10 \\
\hline Homebell (RE) & 0.46 & 0.03 & 50 & 1.25 & 36.4 & $10.3-95.9$ & 4 \\
\hline Gila $1876(\mathrm{HB})^{\mathrm{v}}$ & 0.41 & 0.03 & 51 & 1.44 & 33.9 & $0.0-82.8$ & 5 \\
\hline Bluegem (RE) & 0.40 & 0.02 & 52 & 1.22 & 34.6 & $8.9-79.5$ & 4 \\
\hline Pender (HB) & 0.39 & 0.03 & 53 & 1.48 & 35.2 & $4.2-84.9$ & 3 \\
\hline Wannabe (SHB) & 0.36 & 0.06 & 54 & 2.67 & 64.0 & $46.5-76.9$ & 3 \\
\hline Blue Ridge (SHB) & 0.36 & 0.14 & 55 & 5.87 & 55.0 & $26.0-84.9$ & 3 \\
\hline Polaris $(\mathrm{HH})$ & 0.33 & 0.05 & 56 & 2.68 & 58.9 & $46.2-67.8$ & 3 \\
\hline Sampson (SHB) & 0.30 & 0.03 & 57 & 1.31 & 35.5 & $3.8-71.9$ & 4 \\
\hline Sunshine Blue (EX) & 0.29 & 0.05 & 58 & 2.39 & 58.7 & $44.9-71.8$ & 4 \\
\hline Menditoo (RE) & 0.27 & 0.05 & 59 & 2.12 & 21.6 & $10.6-39.3$ & 3 \\
\hline Little Giant (RE-CON) & 0.25 & 0.04 & 60 & 1.72 & 38.1 & $9.3-62.4$ & 3 \\
\hline Friendship (HH) & 0.24 & 0.06 & 61 & 2.72 & 65.8 & $43.8-85.9$ & 3 \\
\hline Ira (RE) & 0.21 & 0.09 & 62 & 2.93 & 21.1 & $6.8-35.0$ & 3 \\
\hline Scammell (HB) & 0.19 & 0.05 & 63 & 1.79 & 39.5 & $0.9-93.5$ & 4 \\
\hline Wolcott (HB) & 0.16 & 0.06 & 64 & 1.26 & 76.8 & $61.3-92.3$ & 2 \\
\hline Bonus (HB) & 0.02 & 0.03 & 65 & 0.61 & 67.0 & $55.7-82.5$ & 3 \\
\hline Avonblue (SHB) & -0.03 & 0.05 & 66 & 0.76 & 45.5 & $22.5-65.1$ & 3 \\
\hline Putte (LB) & -0.10 & 0.03 & 67 & 0.82 & 40.6 & $6.0-86.6$ & 3 \\
\hline Baldwin (RE) & -0.17 & 0.06 & 68 & 1.82 & 65.3 & $6.3-100.0$ & 7 \\
\hline Marimba (SHB) & -0.21 & 0.09 & 69 & 3.02 & 65.0 & $34.4-81.4$ & 3 \\
\hline Misty (SHB) & -0.22 & 0.04 & 70 & 1.92 & 71.2 & $52.8-87.5$ & 3 \\
\hline Tophat (HB) & -0.23 & 0.10 & 71 & 3.42 & 64.9 & $30.7-83.0$ & 3 \\
\hline Star (SHB) & -0.23 & 0.04 & 72 & 1.86 & 69.8 & 54.9-91.2 & 3 \\
\hline
\end{tabular}


during conidia production to enhance infec-

\begin{tabular}{|c|c|c|c|c|c|c|c|}
\hline Accession & Estimate $^{z}$ & $\begin{array}{l}\text { SE of the } \\
\text { estimate }\end{array}$ & Rank & $\begin{array}{l}\text { SD of } \\
\text { rank }\end{array}$ & $\begin{array}{c}\text { Raw } \\
\text { avg. }(\%)^{y}\end{array}$ & $\begin{array}{c}\text { Raw } \\
\text { range }(\%)\end{array}$ & $\begin{array}{l}\text { No. of } \\
\text { years }\end{array}$ \\
\hline$\overline{\text { Caroline Blue (HB) }}$ & -0.24 & 0.04 & 73 & 1.68 & 55.1 & $36.9-83.4$ & 4 \\
\hline Rahi (RE) & -0.27 & 0.05 & 74 & 1.93 & 69.3 & $62.9-75.7$ & 2 \\
\hline Onslow (RE) & -0.32 & 0.06 & 75 & 2.94 & 70.8 & $47.0-94.6$ & 2 \\
\hline Pearl River (SHB-RE) & -0.37 & 0.02 & 76 & 1.54 & 71.9 & $62.4-84.3$ & 3 \\
\hline Santa Fe (SHB) & -0.38 & 0.03 & 77 & 1.81 & 44.7 & $21.3-88.0$ & 4 \\
\hline O’Neal (SHB) & -0.38 & 0.05 & 78 & 3.14 & 57.8 & $3.2-85.1$ & 4 \\
\hline St. Cloud $(\mathrm{HH})$ & -0.39 & 0.05 & 79 & 3.32 & 73.5 & $70.7-77.8$ & 3 \\
\hline Duplin (SHB) & -0.40 & 0.04 & 80 & 2.76 & 59.7 & $19.1-92.2$ & 4 \\
\hline Biloxi (SHB) & -0.42 & 0.03 & 81 & 2.32 & 46.7 & $17.6-92.8$ & 4 \\
\hline Puru (HB) & -0.44 & 0.07 & 82 & 3.67 & 68.0 & $40.2-89.2$ & 3 \\
\hline Maru (RE) & -0.45 & 0.07 & 83 & 4.01 & 70.5 & $43.0-98.0$ & 2 \\
\hline Hannah's Choice (HB) & -0.45 & 0.06 & 84 & 3.08 & 44.6 & $12.2-77.0$ & 2 \\
\hline Gulfcoast (SHB) & -0.48 & 0.02 & 85 & 1.17 & 74.7 & $65.0-81.3$ & 3 \\
\hline Clara (RE) & -0.49 & 0.04 & 86 & 2.02 & 56.3 & $9.2-81.6$ & 4 \\
\hline Goldtraube $(\mathrm{HB})^{\mathrm{v}}$ & -0.52 & 0.08 & 87 & 3.60 & 59.1 & $0.0-98.9$ & 6 \\
\hline Collins (HB) & -0.58 & 0.01 & 88 & 0.84 & 74.8 & $67.9-87.5$ & 3 \\
\hline Black Giant (RE) & -0.63 & 0.06 & 89 & 2.16 & 77.6 & $50.7-91.8$ & 4 \\
\hline Early May (RE) & -0.67 & 0.05 & 90 & 1.80 & 36.8 & $14.4-53.5$ & 3 \\
\hline Ozarkblue (SHB) & -0.67 & 0.02 & 91 & 0.99 & 77.5 & $66.0-88.0$ & 3 \\
\hline Aliceblue (RE) & -0.71 & 0.05 & 92 & 2.13 & 73.5 & $52.9-97.2$ & 3 \\
\hline Sapphire (SHB) & -0.72 & 0.06 & 93 & 2.45 & 30.6 & $11.3-44.2$ & 4 \\
\hline November Glow (EX) & -0.75 & 0.07 & 94 & 2.51 & 55.7 & $21.4-100$ & 3 \\
\hline Woodard (RE) & -0.77 & 0.06 & 95 & 2.32 & 82.4 & $65.9-98.9$ & 2 \\
\hline Cooper (SHB) & -0.82 & 0.05 & 96 & 2.21 & 74.4 & $55.6-93.6$ & 3 \\
\hline Arlen (SHB) & -0.82 & 0.03 & 97 & 1.60 & 46.1 & $13.0-79.2$ & 2 \\
\hline Draper (SHB) & -0.82 & 0.08 & 98 & 3.05 & 45.7 & $20.0-71.4$ & 2 \\
\hline Coville (HB) & -0.83 & 0.05 & 99 & 2.28 & $\mathbf{5 7 . 3}$ & $0.2-96.8$ & 9 \\
\hline Choice (RE) & -0.84 & 0.03 & 100 & 1.47 & 76.9 & $67.4-95.3$ & 3 \\
\hline Bonifacy (HB) & -0.93 & 0.06 & 101 & 1.18 & 67.3 & $40.7-99.1$ & 4 \\
\hline Brightwell (RE) & -0.98 & 0.04 & 102 & 1.10 & 63.7 & $9.8-100.0$ & 8 \\
\hline Summit (SHB) & -1.02 & 0.06 & 103 & 1.23 & 53.4 & $24.7-82.1$ & 2 \\
\hline Columbus (RE) & -1.06 & 0.12 & 104 & 2.44 & 51.6 & $33.4-69.8$ & 2 \\
\hline Snowflake (RE) & -1.07 & 0.03 & 105 & 0.64 & 83.4 & $69.9-96.9$ & 2 \\
\hline Sharpblue (SHB) & -1.18 & 0.02 & 106 & 0.51 & 81.3 & $74.3-93.4$ & 3 \\
\hline Emerald (SHB) & -1.26 & 0.05 & 107 & 1.58 & 83.3 & $72.1-96.9$ & 3 \\
\hline Bluecrop (HB) & -1.28 & 0.03 & 108 & 1.21 & 73.8 & $42.7-96.2$ & 4 \\
\hline Magnolia (SHB) & -1.29 & 0.03 & 109 & 1.56 & 86.0 & $77.1-94.4$ & 4 \\
\hline Southland (RE) & -1.29 & 0.03 & 110 & 1.57 & 83.4 & $68.3-98.1$ & 3 \\
\hline Millennia (SHB) & -1.33 & 0.04 & 111 & 1.45 & 92.1 & $88.6-95.7$ & 3 \\
\hline Cape Fear (SHB) & -1.37 & 0.06 & 112 & 1.81 & 81.0 & $70.1-88.2$ & 3 \\
\hline Chaucer (RE) & -1.40 & 0.07 & 113 & 1.81 & 85.4 & $61.8-97.3$ & 3 \\
\hline Climax (RE) & -1.43 & 0.04 & 114 & 0.75 & 78.8 & $25.5-99.6$ & 6 \\
\hline Tifblue (RE) & -1.49 & 0.06 & 115 & 1.92 & 72.8 & $41.4-99.4$ & 6 \\
\hline Ethel (RE) & -1.51 & 0.02 & 116 & 0.78 & 85.2 & $76.2-93.2$ & 3 \\
\hline Beckyblue (RE) & -1.52 & 0.02 & 117 & 0.94 & 88.7 & $74.0-96.2$ & 3 \\
\hline Windy (RE) & -1.57 & 0.03 & 118 & 0.64 & 85.8 & $78.0-91.4$ & 3 \\
\hline Flordablue (SHB) & -1.62 & 0.09 & 119 & 2.29 & 81.3 & $65.2-90.2$ & 3 \\
\hline Powderblue (RE) & -1.63 & 0.04 & 120 & 1.24 & 89.9 & $72.4-100.0$ & 4 \\
\hline Briteblue (RE) & -1.63 & 0.02 & 121 & 0.61 & 87.3 & $78.3-95.6$ & 3 \\
\hline Suwanee (RE) & -1.87 & 0.11 & 122 & 1.63 & 65.0 & $29.0-98.0$ & 4 \\
\hline Bonita (RE) & -1.89 & 0.05 & 123 & 1.17 & 79.3 & $58.9-95.2$ & 3 \\
\hline Satilla (RE) & -1.90 & 0.05 & 124 & 1.25 & 99.2 & $99.0-99.4$ & 2 \\
\hline Austin (RE) & -1.91 & 0.03 & 125 & 1.03 & 90.3 & $81.5-99.1$ & 2 \\
\hline Bluegold (HB) & -2.00 & 0.05 & 126 & 0.84 & 72.0 & $51.9-92.1$ & 2 \\
\hline Owen (RE) & -2.12 & 0.06 & 127 & 0.99 & 62.6 & $48.8-76.5$ & 3 \\
\hline Blue Rose (HB) & -2.12 & 0.03 & 128 & 0.69 & 85.1 & $63.4-99.4$ & 4 \\
\hline Jubilee (SHB) & -2.17 & 0.05 & 129 & 0.86 & 81.7 & $45.3-97.6$ & 4 \\
\hline Denise Blue (HB) & -2.30 & 0.06 & 130 & 0.66 & 93.6 & $82.7-93.5$ & 4 \\
\hline Northblue (HH) & -2.33 & 0.07 & 131 & 0.50 & 76.9 & $31.0-96.7$ & 11 \\
\hline Jewel (SHB) & -2.47 & 0.09 & 132 & 0.25 & 76.9 & $57.7-99.1$ & 4 \\
\hline Florida Rose (RE) & -3.56 & 0.12 & 133 & 0.00 & 86.0 & $71.9-100.0$ & 2 \\
\hline Ochlockonee (RE) & -3.98 & 0.07 & 134 & 0.00 & 79.7 & $63.6-95.9$ & 2 \\
\hline
\end{tabular}
still green, at 4 to 6 weeks after flowering, and stored at $4{ }^{\circ} \mathrm{C}$ until evaluated. Fruit were sliced in half crosswise and observed for the distinctive white fungal growth pattern of the mummy berry pathogen. The incidence of mummy berry fruit infection was expressed as a percentage of the total number of fruit on each plant. The mean number of fruit evaluated per cultivar per year was 91 with a SD of 61 .

Cultivar ranking methodology. Previous research determined that year-to-year variability in manifestation of both phases of mummy berry disease is high, requiring 6 to 8 years of testing to establish reliable resistance estimates (Ehlenfeldt et al., 2010). Because it is not practical to test a large number of cultivars for the needed number of years, we ranked cultivars for the years in which data were available.

There are many methods available that might be used to create rankings when the items to be ranked occur together in combinations that leave large gaps, like in our data in which only a few cultivars were present in most years. Thus, any ranking system needs to work when most cultivars have only a spotty representation in the data set. This is a relatively easy exercise if there is no year $x$ cultivar interaction. However, in the presence of a year $\times$ cultivar interaction, like in our data, there is considerable uncertainty in how a cultivar would have performed in a year for which there are no data for that cultivar, which makes ranking problematic. We tried a number of different published ranking methods [e.g., best linear unbiased predictors using mixed models, e.g., Hill and Rosenberger (1985); generalization of the Bradley-Terry model, e.g., Graves et al. (2003); Hunter (2004)] and found them to produce contradictory rankings with each other (not only for our data set, but also for the demonstration data sets in the publications), and none appeared to effectively capture our intuitive understanding of the data. The method we developed produces stable rankings that match our intuitive understanding of the data and also produces estimates of uncertainty about the ranking. The method is based on principal component analyses and resampling. Essentially, it resolves year-to-year disease incidence contradictions by averaging but qualifies this process in that less "stable" cultivars will have greater uncertainty associated with their final ranking. The use of principal components allows the scale (i.e., fluctuations in yearly average disease incidence) to differ from year to year. This allows cultivars only present in "low" disease incidence years to be compared with those present in "high" disease incidence years. Because most cultivars have fewer than the requisite number of years required for reliable estimates of disease incidence, the rankings we produced should be viewed as preliminary, although the positions of standards may be considered as better established. Our analysis begins by calculating a mean disease incidence (on the arcsine transformed scale) for each 
cultivar-year combination and by removing any cultivar that is not present for at least 2 years of testing. We then randomly sample 2 years from our data set and stop when we find 2 years that share at least two cultivars (because standards were present in most years for both mummy blight and fruit rot data sets, typically many cultivars were shared for randomly selected pairs of years). We use a principal components analysis to determine an axis that best goes through the data sets for the 2 years (this is analogous to a Type II regression finding the line that minimizes the sums for squares for both years equally as opposed to the typical Type I regression that minimizes sums of squares in the vertical direction only) and store this result as the first column in a matrix of 1000 columns (each row is a cultivar). This column will contain a score (a projected value) for each of the cultivars present in both years. Cultivars present in 1 year, but not the other, are regressed on the principal component axis and these predictions used for their values. This process is done repeatedly (999 additional times) for randomly sampled pairs of years. The matrix holding the projected scores then replaces the matrix of original data and the same process is then used for randomly sampled pairs of these projected scores (i.e., two columns from the matrix of 1000 columns are repeatedly resampled). Although a pair of years may have only a few cultivars in common, its resulting projection will have values for all unique cultivars in each year, so there will be fewer "gaps" at this stage. The resulting matrix is again subjected to selection of randomly selected pairs of columns, and this process is continued until all 1000 columns are essentially identical (usually $\approx 20$ total iterations for this data set). This produces a set of scores (i.e., a single score for each cultivar) that can be converted to ranks, if desired. However, we repeat the entire process 30 times so we have 30 scores for each cultivar and use the mean of the 30 scores to produce a ranking. Using the 30 independent estimates of scores for each cultivar, we can also estimate the uncertainty of the scores (or rankings).

\section{Results and Discussion}

Previous research had indicated that both mummy berry blight and mummy fruit rot had a large genotype $\times$ environment interaction component that led to significant variability in the measurement of susceptibility (Ehlenfeldt et al., 2010). It was shown that when using data from a limited number of years (less than 8 years), the se could be severely underestimated (as compared with the SE derived from the full range of data with more variable years included) so that, especially for 2 or 3 years, the mean and an estimate of its SE were less reliable than those from long-term testing.

A wide range of susceptibility (i.e., percent infected) values were observed, especially for standards that were evaluated over many years. The SDS, rank, and SD of the rank are listed for each cultivar in Tables 1 and 2.
Table 2. Mummy fruit infection estimates, ranks, and raw percentages compared with blueberry cultivar standards (bold) listed in order of increasing susceptibility.

\begin{tabular}{|c|c|c|c|c|c|c|c|}
\hline Accession & Estimate $^{z}$ & $\begin{array}{c}\text { SE of } \\
\text { estimate }\end{array}$ & Rank & SD of rank & $\begin{array}{c}\text { Raw } \\
\text { avg. }(\%)^{y}\end{array}$ & $\begin{array}{c}\text { Raw } \\
\text { range }(\%)\end{array}$ & $\begin{array}{l}\text { No. of } \\
\text { years }^{\mathrm{x}}\end{array}$ \\
\hline$\overline{\text { Brunswick (LB) }}{ }^{\mathrm{w}}$ & 3.38 & 0.05 & 1 & 0.00 & 0.1 & $0.0-0.4$ & 3 \\
\hline Northsky (HH) & 3.23 & 0.05 & 2 & 0.82 & 1.7 & $0.0-4.8$ & 11 \\
\hline Chignecto (LB) & 3.21 & 0.05 & 3 & 0.45 & 0.0 & $0.0-0.0$ & 3 \\
\hline Fundy (LB) & 3.19 & 0.05 & 4 & 0.41 & 0.0 & $0.0-0.1$ & 3 \\
\hline Putte (LB) & 3.08 & 0.06 & 5 & 0.00 & 0.1 & $0.0-0.2$ & 2 \\
\hline Pearl River (HB-RE) & 2.94 & 0.05 & 6 & 0.00 & 2.1 & $0.0-7.2$ & 4 \\
\hline Northcountry (HH) & 2.80 & 0.04 & 7 & 0.68 & 0.2 & $0.0-0.7$ & 3 \\
\hline Augusta (LB) & 2.79 & 0.04 & 8 & 0.58 & 4.1 & $0.0-12.3$ & 3 \\
\hline Zuckertraube (LB) & 2.69 & 0.09 & 9 & 0.70 & 2.8 & $0.0-6.5$ & 3 \\
\hline Aron (EX) & 2.37 & 0.13 & 10 & 0.43 & 12.5 & $0.9-24.1$ & 4 \\
\hline St. Cloud (HH) & 2.24 & 0.04 & 11 & 0.31 & 2.7 & $0.0-7.9$ & 3 \\
\hline Ornablue (EX) & 2.12 & 0.04 & 12 & 0.41 & 3.5 & $0.8-8.5$ & 3 \\
\hline Chippewa (HH) & 2.01 & 0.04 & 13 & 0.61 & 2.2 & $0.0-3.5$ & 3 \\
\hline Patriot (HB) & 1.98 & 0.04 & 14 & 0.66 & 10.3 & $0.4-24.6$ & 5 \\
\hline Northblue (HH) & 1.90 & 0.04 & 15 & 0.72 & 8.3 & $3.6-15.8$ & 5 \\
\hline Friendship $(\mathrm{HH})$ & 1.90 & 0.05 & 16 & 0.67 & 4.6 & $0.8-11.6$ & 3 \\
\hline Bluejay (HB) & 1.74 & 0.02 & 17 & 0.45 & 9.8 & $0.2-25.4$ & 11 \\
\hline Weymouth (HB) & 1.73 & 0.03 & 18 & 0.63 & 8.8 & $2.6-15.2$ & 4 \\
\hline Gem (HB) & 1.64 & 0.06 & 19 & 0.67 & 3.4 & $0.3-8.1$ & 3 \\
\hline June (HB) & 1.47 & 0.04 & 20 & 0.92 & 11.2 & $3.3-25.6$ & 4 \\
\hline Bluegold (HB) & 1.47 & 0.05 & 21 & 0.91 & 9.3 & $1.6-18.7$ & 4 \\
\hline Cabot (HB) & 1.44 & 0.05 & 22 & 0.96 & 10.9 & $2.1-28.6$ & 5 \\
\hline Cape Fear (SHB) & 1.37 & 0.09 & 23 & 1.43 & 7.8 & $0.0-14.4$ & 3 \\
\hline Reka (HB) & 1.33 & 0.05 & 24 & 0.53 & 9.1 & $2.9-22.7$ & 4 \\
\hline Northland (HB) & 1.24 & 0.03 & 25 & 0.40 & 11.4 & $3.4-22.6$ & 4 \\
\hline Wolcott (HB) & 1.19 & 0.05 & 26 & 0.63 & 14.8 & $1.8-36.3$ & 4 \\
\hline Polaris $(\mathrm{HH})$ & 0.79 & 0.04 & 27 & 0.57 & 6.2 & $1.6-8.7$ & 3 \\
\hline Puru (HB) & 0.78 & 0.04 & 28 & 0.76 & 8.7 & $6.1-12.8$ & 3 \\
\hline Nui (HB) & 0.68 & 0.04 & 29 & 1.29 & 8.7 & $6.0-12.1$ & 3 \\
\hline Harrison (HB) & 0.67 & 0.06 & 30 & 1.76 & 15.2 & $2.6-26.4$ & 4 \\
\hline Little Giant (RE-CON) & 0.64 & 0.07 & 31 & 1.96 & 11.8 & $1.7-50.0$ & 3 \\
\hline Echota (HB) & 0.63 & 0.06 & 32 & 1.91 & 17.1 & $3.0-35.5$ & 3 \\
\hline Reveille (HB) & 0.61 & 0.04 & 33 & 1.27 & 9.6 & $4.9-17.2$ & 3 \\
\hline Olympia (HB) & 0.59 & 0.05 & 34 & 1.60 & 13.4 & $6.6-26.9$ & 3 \\
\hline Bladen (HB) & 0.52 & 0.03 & 35 & 0.70 & 10.5 & $4.5-17.7$ & 3 \\
\hline Chanticleer (HB) & 0.49 & 0.07 & 36 & 1.39 & 34.3 & $10.0-62.6$ & 3 \\
\hline Harding (HB) & 0.35 & 0.06 & 37 & 1.74 & 17.4 & $4.7-22.5$ & 4 \\
\hline Brigitta Blue (HB) & 0.35 & 0.06 & 38 & 2.13 & 10.3 & $9.1-12.2$ & 3 \\
\hline Rancocas (HB) & 0.34 & 0.04 & 39 & 1.31 & 22.1 & $2.5-58.4$ & 12 \\
\hline Sharpblue (SHB) & 0.32 & 0.05 & 40 & 1.63 & 11.9 & $7.7-20.3$ & 3 \\
\hline Heerma (HB) & 0.30 & 0.06 & 41 & 1.87 & 17.7 & $8.4-25.9$ & 4 \\
\hline Legacy (SHB) & 0.23 & 0.06 & 42 & 1.70 & 26.2 & $4.4-55.5$ & 4 \\
\hline Coville (HB) & 0.19 & 0.07 & 43 & 2.26 & 15.9 & $7.4-25.8$ & 4 \\
\hline Top Hat (HB) & 0.14 & 0.05 & 44 & 1.85 & 15.2 & $7.9-28.6$ & 3 \\
\hline South Moon (SHB) & 0.13 & 0.12 & 45 & 3.17 & 23.9 & $0.0-54.5$ & 3 \\
\hline Meader (HB) & 0.13 & 0.03 & 46 & 1.82 & 12.2 & $5.4-19.2$ & 3 \\
\hline Wareham (HB) & 0.13 & 0.07 & 47 & 2.78 & 18.0 & $3.9-28.0$ & 4 \\
\hline Cara's Choice (SHB) & 0.12 & 0.07 & 48 & 2.88 & 9.0 & $0.4-20.2$ & 3 \\
\hline Bluecrop (HB) & 0.08 & 0.04 & 49 & 1.38 & 18.5 & $8.3-27.4$ & 4 \\
\hline Duke (HB) & 0.04 & 0.06 & 50 & 1.83 & 16.7 & $10.4-22.1$ & 4 \\
\hline Millennia (SHB) & -0.04 & 0.06 & 51 & 1.12 & 42.9 & $10.4-17.6$ & 2 \\
\hline Star (SHB) & -0.13 & 0.08 & 52 & 1.45 & 19.0 & $2.7-47.4$ & 3 \\
\hline Collins (HB) & -0.15 & 0.03 & 53 & 0.88 & 21.5 & $6.2-36.8$ & 4 \\
\hline Gila $1876(\mathrm{HB})^{\mathrm{v}}$ & -0.25 & 0.07 & 54 & 1.55 & 34.7 & $12.1-68.5$ & 3 \\
\hline Pioneer (HB) & -0.27 & 0.04 & 55 & 1.23 & 20.4 & $8.5-30.3$ & 4 \\
\hline Bounty (HB) & -0.33 & 0.04 & 56 & 1.97 & 16.9 & $10.6-27.8$ & 3 \\
\hline Bluetta (HB) & -0.34 & 0.08 & 57 & 3.02 & 18.0 & $3.4-39.5$ & 4 \\
\hline Rubel (HB) & -0.36 & 0.06 & 58 & 2.93 & 22.3 & $6.9-51.1$ & 4 \\
\hline O’Neal (SHB) & -0.38 & 0.03 & 59 & 1.79 & 20.6 & $7.3-27.4$ & 3 \\
\hline Spartan (HB) & -0.40 & 0.08 & 60 & 3.23 & 23.9 & $14.0-37.7$ & 4 \\
\hline Sunrise (HB) & -0.45 & 0.05 & 62 & 2.43 & 17.2 & $11.6-22.8$ & 3 \\
\hline Hannah’s Choice (HB) & -0.45 & 0.07 & 63 & 3.41 & 29.4 & $6.9-70.1$ & 3 \\
\hline Katharine (HB) & -0.45 & 0.05 & 64 & 3.91 & 25.0 & $9.3-44.9$ & 4 \\
\hline Bonifacy (HB) & -0.46 & 0.06 & 65 & 2.76 & 34.0 & $16.2-61.1$ & 3 \\
\hline Murphy (HB) & -0.46 & 0.03 & 66 & 2.09 & 32.3 & $10.3-47.4$ & 5 \\
\hline Pemberton (HB) & -0.49 & 0.04 & 67 & 2.27 & 23.0 & $9.6-45.3$ & 3 \\
\hline Toro (HB) & -0.55 & 0.08 & 68 & 3.46 & 25.1 & $20.0-39.3$ & 4 \\
\hline Morrow (HB) & -0.55 & 0.04 & 69 & 2.06 & 22.8 & $7.0-44.8$ & 4 \\
\hline Misty (SHB) & -0.56 & 0.05 & 70 & 2.53 & 20.5 & $2.0-41.6$ & 3 \\
\hline Blue Ridge (SHB) & -0.56 & 0.05 & 71 & 1.91 & 17.7 & $9.0-26.8$ & 3 \\
\hline Bluehaven (HB) & -0.58 & 0.04 & 72 & 2.19 & 29.1 & $9.3-45.0$ & 3 \\
\hline Goldtraube $(\mathrm{HB})^{\mathrm{v}}$ & -0.64 & 0.06 & 73 & 2.25 & 29.7 & $13.8-64.7$ & 3 \\
\hline
\end{tabular}




\begin{tabular}{|c|c|c|c|c|c|c|c|}
\hline Accession & Estimate $^{z}$ & $\begin{array}{c}\text { SE of } \\
\text { estimate }\end{array}$ & Rank & SD of rank & $\begin{array}{c}\text { Raw } \\
\text { avg. }(\%)^{y}\end{array}$ & $\begin{array}{c}\text { Raw } \\
\text { range }(\%)\end{array}$ & $\begin{array}{l}\text { No. of } \\
\text { years }\end{array}$ \\
\hline$\overline{\text { Darrow (HB) }}$ & -0.64 & 0.04 & 74 & 2.12 & 21.2 & $13.0-31.5$ & 4 \\
\hline Denise Blue (HB) & -0.65 & 0.04 & 75 & 1.25 & 36.8 & $9.0-72.5$ & 3 \\
\hline Grover (HB) & -0.72 & 0.05 & 76 & 1.85 & 32.0 & $6.2-67.8$ & 3 \\
\hline Ozarkblue (SHB) & -0.73 & 0.03 & 77 & 0.88 & 25.3 & $18.7-33.3$ & 3 \\
\hline Avonblue (SHB) & -0.74 & 0.07 & 78 & 2.66 & 21.0 & $2.0-51.6$ & 4 \\
\hline Summit (SHB) & -0.81 & 0.04 & 79 & 1.40 & 25.0 & $15.5-34.5$ & 2 \\
\hline Concord (HB) & -0.83 & 0.04 & 80 & 2.23 & 28.7 & $8.8-46.1$ & 4 \\
\hline Nelson (HB) & -0.83 & 0.05 & 81 & 1.52 & 32.2 & $18.6-64.8$ & 4 \\
\hline Windsor (HB) & -0.85 & 0.05 & 82 & 2.94 & 24.3 & $9.8-40.6$ & 3 \\
\hline Jersey (HB) & -0.87 & 0.03 & 83 & 1.57 & 24.8 & $12.8-38.6$ & 4 \\
\hline Cooper (SHB) & -0.90 & 0.04 & 84 & 1.38 & 20.2 & $14.5-26.0$ & 3 \\
\hline Wannabe (SHB) & -0.93 & 0.05 & 85 & 2.52 & 28.2 & $4.0-57.4$ & 3 \\
\hline Ivanhoe (HB) & -0.95 & 0.06 & 86 & 3.35 & 30.0 & $7.4-50.0$ & 4 \\
\hline Gulfcoast (SHB) & -0.95 & 0.04 & 87 & 1.58 & 21.2 & $8.0-40.3$ & 3 \\
\hline Pender (HB) & -0.96 & 0.04 & 88 & 2.22 & 37.4 & $9.5-56.2$ & 3 \\
\hline Dixi (HB) & -0.98 & 0.05 & 89 & 2.28 & 28.0 & $17.5-44.1$ & 4 \\
\hline Croatan (HB) & -1.01 & 0.07 & 90 & 2.76 & 34.8 & $6.9-58.4$ & 5 \\
\hline Greta $(\mathrm{HB})^{\mathrm{v}}$ & -1.05 & 0.05 & 91 & 2.31 & 40.2 & $16.1-70.7$ & 3 \\
\hline Elizabeth (HB) & -1.05 & 0.06 & 92 & 2.19 & 29.2 & $7.4-52.1$ & 4 \\
\hline Chandler (HB) & -1.07 & 0.05 & 93 & 1.87 & 61.6 & $43.3-79.8$ & 3 \\
\hline Ama (HB) & -1.12 & 0.03 & 94 & 0.87 & 30.5 & $12.3-46.5$ & 4 \\
\hline Earliblue (HB) & -1.14 & 0.07 & 95 & 1.70 & 31.2 & $18.9-49.0$ & 4 \\
\hline Bluechip (HB) & -1.23 & 0.03 & 96 & 1.05 & 30.4 & $13.6-47.3$ & 4 \\
\hline Ascorba $(\mathrm{HB})^{\mathrm{v}}$ & -1.26 & 0.03 & 97 & 2.08 & 44.6 & $22.0-73.7$ & 3 \\
\hline Burlington (HB) & -1.26 & 0.09 & 98 & 3.23 & 30.9 & $17.5-57.0$ & 4 \\
\hline $11-104(\mathrm{HB})$ & -1.27 & 0.03 & 99 & 1.53 & 28.2 & $17.7-42.2$ & 4 \\
\hline Stanley (HB) & -1.29 & 0.03 & 100 & 1.50 & 30.4 & $16.2-44.8$ & 4 \\
\hline Blueray (HB) & -1.30 & 0.07 & 101 & 3.01 & 35.8 & $7.8-70.9$ & 12 \\
\hline Blue Rose (HB) & -1.31 & 0.06 & 102 & 3.11 & 64.0 & $51.7-72.7$ & 3 \\
\hline Jubilee (SHB) & -1.34 & 0.04 & 103 & 2.00 & 48.1 & $16.8-55.3$ & 3 \\
\hline Hardyblue (HB) & -1.35 & 0.06 & 104 & 2.20 & 32.8 & $15.4-58.8$ & 4 \\
\hline Georgiagem (SHB) & -1.40 & 0.04 & 105 & 1.66 & 29.1 & $7.7-56.7$ & 3 \\
\hline Bonus (HB) & -1.42 & 0.04 & 106 & 1.30 & 38.3 & $15.6-59.2$ & 3 \\
\hline Elliott (HB) & -1.46 & 0.06 & 107 & 1.38 & 31.2 & $12.9-55.4$ & 4 \\
\hline Lateblue (HB) & -1.62 & 0.05 & 108 & 0.88 & 31.8 & $16.8-27.0$ & 3 \\
\hline Angola (HB) & -1.63 & 0.07 & 109 & 1.05 & 30.4 & $11.4-61.3$ & 3 \\
\hline Sierra (SHB) & -1.65 & 0.05 & 110 & 0.70 & 41.4 & $3.6-90.4$ & 12 \\
\hline Marimba (SHB) & -1.82 & 0.04 & 111 & 0.43 & 45.6 & $22.7-61.3$ & 3 \\
\hline Sunshine Blue (EX) & -1.87 & 0.05 & 112 & 0.38 & 45.7 & $11.0-80.8$ & 5 \\
\hline Herbert (HB) & -2.07 & 0.04 & 113 & 0.00 & 37.5 & $15.1-61.1$ & 4 \\
\hline Flordablue (SHB) & -2.25 & 0.08 & 114 & 0.66 & 41.6 & $7.5-85.7$ & 3 \\
\hline Berkeley (HB) & -2.37 & 0.06 & 115 & 0.61 & 45.5 & $29.1-65.7$ & 4 \\
\hline Magnolia (SHB) & -2.47 & 0.17 & 116 & 0.73 & 77.6 & $71.8-89.2$ & 3 \\
\hline Atlantic (HB) & -3.02 & 0.05 & 117 & 0.00 & 56.1 & $12.2-89.6$ & 12 \\
\hline
\end{tabular}

${ }^{2}$ Estimate derived by principal component analysis and resampling and averaging of paired years of data (see "Materials and Methods").

yAverage percent infection across all years tested.

${ }^{x}$ The number of years the cultivar was screened for resistance.

${ }^{\mathrm{w}} \mathrm{HB}=$ highbush (primarily $V$. corymbosum); $\mathrm{SHB}=$ southern highbush (primarily $V$. corymbosum introgressed by $V$. darrowii); $\mathrm{RE}=$ rabbiteye $(V$. ashei, $V$. virgatum $) ; \mathrm{LB}=$ lowbush $(V$. angustifolium $)$ $\mathrm{HH}=$ half-high $(V$. corymbosum $-V$. angustifolium hybrids); $\mathrm{CON}=V$. constablaei $; \mathrm{EX}=$ exotic (usually $V$. corymbosum introgressed by a less typical Vaccinium species).

${ }^{v}$ These cultivars are the result of repeated hybridization and selection in a V. corymbosum-V. angustifolium population, but most are highbush-like in stature and habit.

The few cultivars that were less susceptible than any standards for either blighting or fruit infection achieved this ranking by being less susceptible than the standard for all or most years. A few of the more highly susceptible cultivars (especially for fruit infection) exhibited low variation because they were consistently at or near $100 \%$ infection.

If ranks based on raw data are compared with the information from our estimation process, one can see that the raw percentages do not necessarily follow the rankings determined by our methodology because the years in which a cultivar is evaluated greatly impacts its disease incidence, so the derived ranks are superior to the raw values for comparisons. As an example of how raw disease incidence can be misleading, consider the apparently anomalous placement of 'Aron', which has both a low raw average and a low raw range yet only ranks fifth best. What is not apparent is that although 'Aron' had a susceptibility value of only $0.5 \%$ in 2001, in the same year, 'Coville', a long-term standard that we ranked as $99 / 134$ in our system and whose long-term raw disease incidence was $57.3 \%$, had a disease incidence value of only $0.2 \%$. This anomalously low value for 'Coville' in 2001 presents a problem for the evaluation, by standard means, of other cultivars present in that year. Our methodology deals with this kind of problem and ultimately ranks 'Aron' as relatively resistant, but also produces a SE of its estimate that is larger than those for cultivars at the top of the list. Ultimately (and realistically), its position is lower than expected based strictly on its raw average and range. Similar considerations come into play when ranking other cultivars.

Our rankings do not aim to identify statistically significant differences and with the limited number of years of data for most cultivars, few would be found. Because often the goal of studies such as this is to identify the best or the worst among cultivars, it is reasonable to believe however that the cultivars estimated to be less susceptible have a true lower susceptibility. A analogous assumption may be made among the more susceptible cultivars. In the middle ranks, fewer conclusions can be drawn, and careful judgment must be used. This uncertainty is reflected in their more variable score estimates and rankings.

If we look broadly at the cultivars screened for blight resistance, lowbush types appear to be less susceptible with four lowbush cultivars among the 10 least susceptible cultivars. Note, however, that 'Putte' (also lowbush) is ranked 67 and thus relatively susceptible. The resistance seen in lowbush or lowbush-derived material is even more pronounced in cultivars evaluated for fruit infection with six of the 10 least susceptible cultivars being lowbush and another two being half-high types.

A simple correlation of transformed disease scores for cultivars that were tested for both phases of the disease $(n=72)$ reveals a positive and significant correlation of $r=$ $0.33(P=0.005)$ (Fig. 1). In contrast, Stretch and Ehlenfeldt (2000) in a similar correlation with data covering 48 cultivars over a 3-year period found no correlation and a negative $r$ value ( $r=-0.245, P=0.093)$. The most likely explanation for this discrepancy is that our data cover many more cultivars, giving it greater statistical strength, but is also enriched with both lowbush and half-high cultivars that tend to have low scores for both phases of the disease.

Across all cultivars, 'Brunswick' lowbush was the most resistant to both phases of mummy berry and could be a useful source of resistance; however, using lowbush germplasm in a highbush breeding program presents a significant challenge to achieve the retention of disease resistance during backcrossing or field selection while also recovering standard highbush horticultural type. Thus, although 'Brunswick' may be the mummy berry resistance "source of choice," it may not be the parent of choice. Among highbush cultivars (and thus more adapted material), 'Bluejay', which has been used as a standard for long-term evaluations, clearly stands out as being among the most resistant to both phases of mummy berry and has the benefit of exhibiting this resistance with a high degree of reliability. 


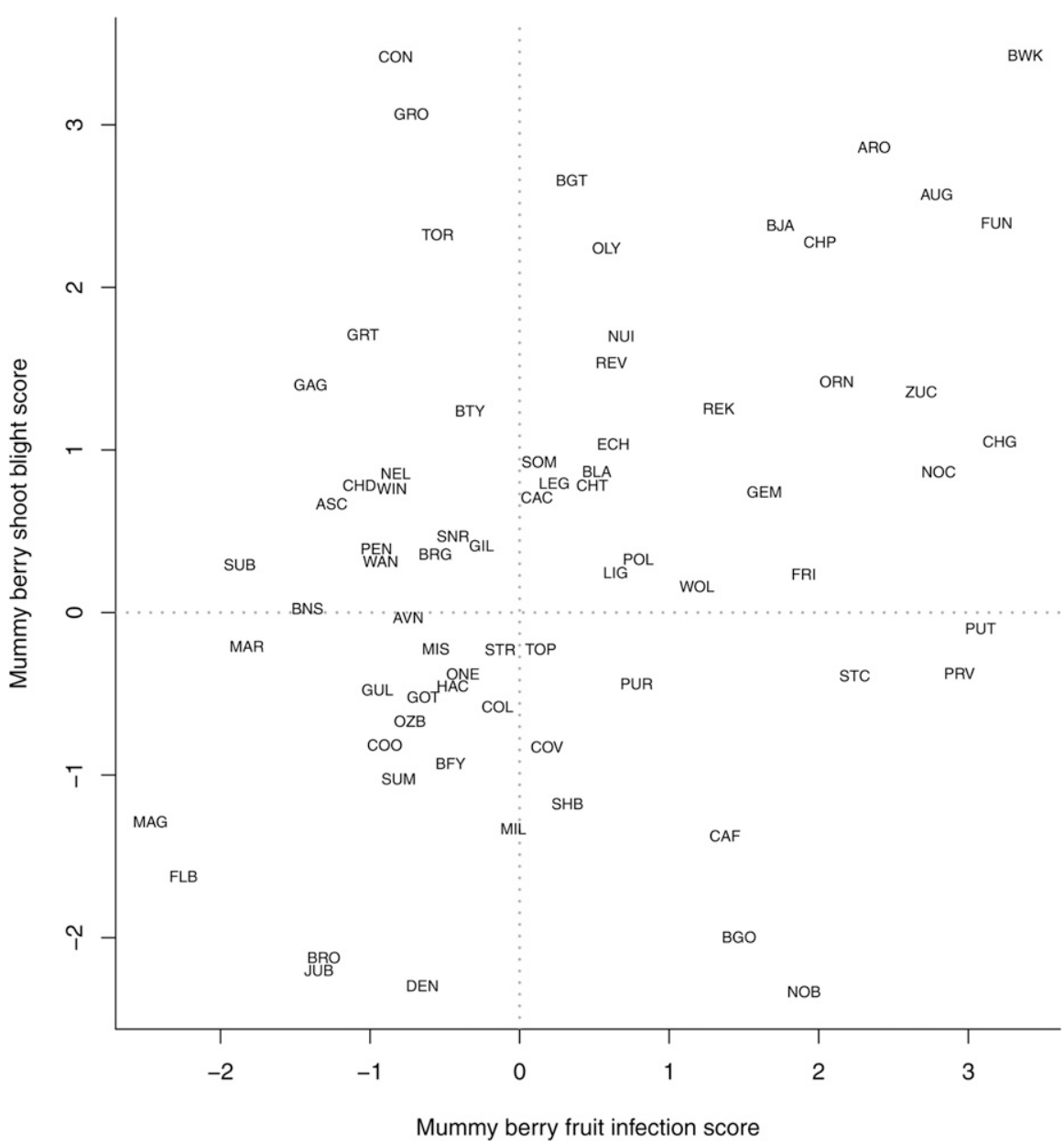

Fig. 1. Mummy berry shoot blight scores versus mummy berry fruit infection scores for 72 blueberry cultivars scored for both phases of the disease. Higher scores indicate greater resistance.

\section{Literature Cited}

Batra, L.R. 1983. Monilinia vaccinii-corymbosi (Sclerotiniaceae): Its biology on blueberry and comparison with related species. Mycologia $75: 131-152$.

Batra, L.R. and S.W.T. Batra. 1985. Floral mimicry induced by mummy-berry fungus exploits host's pollinators as vectors. Science 228: 1011-1013.

Ehlenfeldt, M.K., J.J. Polashock, A.W. Stretch, and M. Kramer. 2006. Leaf disk infection by Colletotrichum acutatum and its relation to
Ehlenfeldt, M.K. and A.W. Stretch. 2000. Mummy berry blight resistance in rabbiteye blueberry cultivars. HortScience 35:1326-1328.

Ehlenfeldt, M.K., A.W. Stretch, and V. Brewster. 1996. Genetic and morphological factors influence mummy berry blight resistance in highbush blueberry. HortScience 31:252-254.

Ehlenfeldt, M.K., A.W. Stretch, and J.S. Lehman. 1997. Shoot length affects susceptibility to mummy berry blight within highbush blueberry cultivars. HortScience 32:884-887.

Graves, T., C.S. Reese, and M. Fitzgerald. 2003. Hierarchical models for permutations: Analysis of auto racing results. J. Am. Stat. Assoc. 98: 282-291.

Hildebrand, P.D., R.D. Milholland, and A.W Stretch. 1995. Mummy berry, p. 11-12. In: Caruso, F.L. and D.C. Ramsdell (eds.). Compendium of blueberry and cranberry diseases. American Phytopathological Society Press, St., Paul, MN.

Hill, R.R., Jr. and J.L. Rosenberger. 1985. Methods for combining data from germplasm evaluation trials. Crop Sci. 25:467-470.

Hunter, D.R. 2004. MM Algorithms for generalized Bradley-Terry models. Ann. Stat. 32:384406.

Lehman, J.S., S. Igarashi, and P.V. Oudemans. 2007. Host resistance to Monilinia vacciniicorymbosi in flowers and fruits of highbush blueberry. Plant Dis. 91:852-856.

Lynch, R.E., B. Guo, P. Timper, and J.P. Wilson. 2003. United States Department of AgricultureAgricultural Research Service research on improving host-plant resistance to pests. Pest Manag. Sci. 59:718-727.

Pepin, H.S. and H.N.W. Toms. 1969. Susceptibility of highbush blueberry varieties to Monilinia vaccinii-corymbosi. Phytopathology 59:18761878.

Polashock, J.J., M.K. Ehlenfeldt, A.W. Stretch, and M. Kramer. 2005. Anthracnose fruit rot resistance in blueberry cultivars. Plant Dis. 89:33-38.

Polashock, J.J. and M. Kramer. 2006. Resistance of blueberry cultivars to Botryosphaeria stem blight and Phomopsis twig blight. HortScience 41:1457-1461.

fruit rot in diverse blueberry germplasm. HortScience 41:270-271.

Ehlenfeldt, M.K., J.J. Polashock, A.W. Stretch, and M. Kramer. 2009. Mummy berry fruit rot and shoot blight incidence in blueberry: What length of evaluation is needed for reliable disease assessment? HortScience 44:1002 (abstr.).

Ehlenfeldt, M.K., J.J. Polashock, A.W. Stretch, and M. Kramer. 2010. Mummy berry fruit rot and shoot blight incidence in blueberry: Prediction, ranking, and stability in a long-term study. HortScience 45:92-97.
Stretch, A.W and M.K. Ehlenfeldt. 2000. Resistance to the fruit infection phase of mummy berry disease in highbush blueberry cultivars. HortScience 35:1271-1273.

Stretch, A.W., M.K. Ehlenfeldt, and V. Brewster. 1995. Mummy berry blight resistance in highbush blueberry cultivars. HortScience 30:589-591.

Stretch, A.W., M.K. Ehlenfeldt, V. Brewster, N. Vorsa, and J. Polashock. 2001. Resistance of diploid Vaccinium spp. to the fruit rot stage of mummy berry disease. Plant Dis. 85:27-30. 